\title{
NOSTALGIA W POEZJI STANISŁAWA BARAŃCZAKA
}

\author{
NOSTALGIA IN STANISŁAW BARAŃCZAK'S POETRY
}

\author{
AGNIESZKA RYDZ
}

\begin{abstract}
The article Nostalgia in Stanistaw Barańczak's Poetry was inspired by Douwe Draaisma's essay, a Dutch psychology theoretician, The Fabric of Nostalgia. About the Phenomenon of Mature Memory's Age (2010). This model of nostalgia is based on the psychological phenomenon of memory reminiscence. The article presents the evolution of theme of nostalgia in Barańczak's poetry.
\end{abstract}

Keywords: Stanisław Barańczak, Douwe Draaisma, Polish poetry, memory, nostalgia

Agnieszka Rydz, Uniwersytet im. Adama Mickiewicza w Poznaniu, Poznań - Polska, agryd@amu.edu.pl

ORCID ID: 0000-0002-4676-6090

\section{Przednowoczesna nostalgia}

Po-/post-/późno-nowoczesna nostalgia jest pojęciem, które występuje w licznych związkach semantycznych z innymi zjawiskami, mniej lub bardziej pokrewnymi, przy czym mogą być one zróżnicowane pod względem formy i znaczeń nadawanych im przez użytkowników rozmaitych dyskursów: medycznego, psychiatrycznego, psychologicznego, socjologicznego, filozoficznego, kulturoznawczego, politologicznego, historycznego i wreszcie literaturoznawczego. Toteż w pełni uprawnione będzie posługiwanie się pojęciem dyskurs w sensie, jaki nadał mu Michel Foucault w wykładzie inauguracyjnym z 1970 roku, przy okazji obejmowania profesury w College de France, a dużo później opublikowanym w Polsce jako Porządek dyskursu (2002) w odniesieniu do nostalgii doświadczanej w dwudziestym wieku i obecnie. Przy czym dyskurs nostalgii występowałby równocześnie i równolegle, niekiedy znajdując punkty styczne z innymi formami ponowoczesnej społecznej dyskusji: memorialną, medyczną, afektywną, by ograniczyć się tu do podania trzech najbardziej wyrazistych reprezentacji.

Znaczenie rzeczownika "nostalgia” notowane przez Słownik języka polskiego przedstawia się następująco: nostalgia to "tęsknota za krajem ojczystym" [Słownik jezzyka polskiego PWN 2004]. Definicja powyższa wykazuje zgodność z potocznym i dobrze zakorzenionym $\mathrm{w}$ tradycji wyobrażeniem kulturowym, 
które przede wszystkim łączy nostalgię ze specyficznym modelem egzystencji człowieka, jakim jest emigracja, choć - jak postaram się to dalej udowodnić występuje jeszcze inna, później sformułowana możliwość rozumienia terminu. Dowiadujemy się z leksykonu, że można: „Odczuwać nostalgię / Cierpieć na nostalgię" [Słownik języka polskiego PWN 2004]. Dlatego nostalgia oglądana w świetle słownikowej definicji przynależy do dyskursu afektywnego, gdzie jest waloryzowana zdecydowanie i jednoznacznie ujemnie jako zespół negatywnych emocji odczuwanych przez emigranta. Porównać by ją można do lawiny, która, gdy nagle zejdzie, uruchomi całą sekwencję negatywnych symptomów. Będzie nie do zatrzymania w swym niszczycielskim żywiole, nieustępliwa i groźna w skutkach, eskalująca emocje aż do ekstremalnego stanu, co sugeruje gradacja użyta w deskrypcji hasła w słowniku: „Nostalgia dokucza komuś, ogarnia, trawi, zżera" [Stownik języka polskiego 2010]. Również badania psychologów prowadzone w XXI wieku dowodzą ponad wszelką wątpliwość, że nostalgia burzy spokój pojedynczego człowieka i całych rodzin, wywołuje konflikty wśród bliskich sobie osób, z których jedne chcą pozostać $\mathrm{w}$ nowym kraju, a inne wrócić $\mathrm{w}$ rodzinne strony [Draaisma 2010: 170]. Słowem - zatruwa ona egzystencję oraz jątrzy domowy spokój na podobieństwo zainfekowanej rany, przez co jest bardzo trudna do wyleczenia. Gdy w końcu kiedyś zagoi się szczęśliwie, to i tak pozostawi po sobie widoczne blizny, zrosty życiowych pęknięć i ślady osobistych rozłamów.

Również przednowoczesne rozumienie pojęcia nostalgii odsyła do emocji zagrażających człowiekowi, przy czym nie tylko jego dobrostanowi psychicznemu, ale w ogóle zdrowiu, a w szczególnych sytuacjach nawet samemu życiu. Pomysłodawca terminu, Johannes Hofer, szwajcarski lekarz, utworzył go w roku 1678 w opisie zagadkowej przypadłości fizycznej, na jaką zapadł młodzieniec przybyły z Berna do Bazylei na studia, odczuwający w nowym miejscu dojmującą tęsknotę za domem, która uniemożliwiła mu realizację celu edukacyjnego, z jakim dotarł do uniwersytetu. Zresztą, wkrótce potem postawiła ona pod znakiem zapytania całą jego dalszą egzystencję, ponieważ: „Stracił apetyt, widocznie schudł i w końcu jego kondycja fizyczna tak się pogorszyła, że obawiano się o jego życie" [Draaisma 2010: 172].

Medyk na określenie nazwy choroby użył słowa zaczerpniętego ze szwajcarskiego dialektu Heimweh. Po czym dokonał jego osobliwej translacji, bo przekładając je na starą grekę tak oto, że połączył wyraz „nostos” oznaczający powrót do domu z innym, "algos", co znaczy: „ból” i tym samym powstał neologizm „nostalgia” [Draaisma 2010: 172-173]. Termin ten zrobił w siedemnastowiecznej i osiemnastowiecznej Europie oszołamiającą karierę oraz wywołał swoistą modę na nostalgię, która utrzymywała się przez całe dziewiętnaste stulecie. Dopiero w dwudziestym wieku nostalgia zatraciła swe pierwotne znaczenie i rozpoczął się zmierzch pojęcia w medycynie. Przypo- 
mina o tym fakcie współczesny Szwajcar, Jean Starobinski, odtwarzając etapy zawłaszczania coraz to większych obszarów doświadczenia przez niegdysiejszą nostalgię. Punktem wyjścia dla swoich rozważań uczynił on pytanie, czy zjawisko istniało wcześniej, jeszcze przed tak fortunnym wynalezieniem jego nazwy? Odpowiedź jest twierdząca: „Ludzie odczuwali nostalgię, zanim to uczucie zyskało naukowe miano, podobnie jak sadyzm istniał przed markizem de Sade, a Ziemia obracała się przed Kopernikiem" [Starobinski 2017: 206]. Oczywiście: był Homer i Odys, był Owidiusz, ów wygnaniec starożytnego świata piszący swe Tristia (dosł. „żale”, łac.) z dala od przepychu kultury i osiągnięć cywilizacyjnych Rzymu, bo na terenach odpowiadających dzisiejszej Rumunii. Przede wszystkim zaś istniała tęsknota miłosna, świetnie udokumentowana w literaturze medycznej, a także w sztukach pięknych dawnych epok, zwana z łacińska desiderium, a oznaczająca melancholię po stracie ukochanej osoby. Toteż nowo odkry te w XVIII wieku desiderium patriae padło na podatny grunt głębokiego smutku, obecny już w kulturze od dawna, a jakżeż zgubny dla równowagi oraz zdrowia podmiotu pożądania, tracącego swe zmysły w konfrontacji z utratą obiektu miłości na zawsze. Okazało się, że w tym konkretnym przypadku nazwa była wprost nie do przecenienia: krążąca w powszechnym, bo nie tylko medycznym użyciu, łatwa do przyswojenia $w$ wielu językach oraz podparta naukowym autorytetem rozprawy doktorskiej szerzyła się, nie przymierzając - gdyż porównanie będzie całkiem współczesne i kłócące się z epoką, do której się odnosi - niczym groźny wirus. Termin będąc werbalnym znakiem zjawiska, dla którego wcześniej nie miano określenia, dał więc asumpt do rozpatrywania nostalgii na uniwersytetach $\mathrm{w}$ całej Europie. Tym samym umocnił przejawy nostalgii w kulturze oraz wykreował modną chorobę. Pacjentom umożliwił odkrycie i rozpoznanie we własnym ciele niepokojących symptomów niebezpiecznego schorzenia, a lekarzy zmobilizował do szukania na nie skutecznego remedium. Występuje również rewers kulturowych praktyk nazywania, wyodrębniania i wyróżniania nowych zjawisk w języku. Za konkluzję wątku onomastycznego w historii nostalgii posłużyć może kolejne spostrzeżenie Starobinskiego, który uważa, że nazwa stanu emocjonalnego wyrażona w języku ma także, poza lingwistycznymi, konsekwencje kulturowe prowokując zachowania, dla których nazwa jest czynnikiem wywoławczym i poniekąd popychającym do działania: „Samobójstwa popełniano, zanim Goethe napisał swego Wertera, ale są ludzie, którzy nigdy nie popełniliby samobójstwa, gdyby nie przeczytali wcześniej Wertera" [Starobinski 2017: 205-206].

W dyskursie przednowoczesnej nostalgii jest również miejsce na, by tak rzec, wątek muzyczny. Otóż, Theodor Zwinger, Szwajcar, o którym jeszcze nie było mowy, w rozprawie z 1720 roku, napisanej w języku łacińskim, dowiódł, że u przyczyn nostalgii szwajcarskich żołnierzy stacjonujących we Francji oraz Bel- 
gii tkwiła pamięć lokalnych melodii, piosenek śpiewanych w rodzimych stronach. Zabroniono tedy śpiewu najemnym żołnierzom, ponieważ nie tylko nie koił on ich smutku, lecz uruchamiał: „fatalny proces: piosenki te prowokowały coraz więcej wspomnień wiążących się z domem, i w końcu żołnierze ci potrafili myśleć wyłącznie o domu, w skrajnych wypadkach umierali na budzącą przerażenie nostalgię" [Draaisma 2010: 173-174]. Dawne szpitale pełne były pacjentów uskarżających się na dotkliwą bezsenność, brak apetytu, apatię, i właśnie takie objawy tworzyły kliniczny obraz nostalgii, z którą jako pierwsi zetknęli się lekarze wojskowi. Powszechnie panował pogląd, że nostalgię skutecznie uleczyć może wyłącznie powrót do domu. Poza tym wierzono, że gdy uniemożliwi się nostalgikowi odesłanie do rodziny, niechybnie popełni on samobójstwo, potwierdzając własnym życiem „piękną i straszną maksymę krążącą ówcześnie w wojsku: „Qui patriam quaerit, mortem venit” („Kto ojczyzny szuka, śmierć znajduje") [Starobinski 2017: 194]. Całkiem zrozumiałe w tej sytuacji było, że robiono wszystko, by tylko zapobiegać chorobie zbierającej śmiertelne żniwo, ponieważ najpoważniejszą konsekwencją dla wojska nie były wcale powikłania medyczne, lecz częste dezercje żołnierzy. Hospitalizacji wówczas raczej nie polecano. Starobinski skwitował ten fakt $z$ właściwym sobie ironicznym dystansem zaznaczając, że było to ze wszech miar słuszne zalecenie zważywszy na ówczesne złe warunki sanitarne: na brud i stłoczenie pacjentów w szpitalach, $\mathrm{z}$ uwagi na panujące praktyki medyczne $\mathrm{w}$ rodzaju upuszczania krwi, jak też ze względu na stan wiedzy medycznej przed odkryciem bakterii oraz wirusologii, a przede wszystkim dlatego, że wymienione czynniki rzeczywiście „przyspieszają fatalny koniec nostalgii" [Starobinski 2017: 198]. Dodam, że ugruntowując w ten sposób równie fatalną „reputację" nostalgii jako ciężkiego schorzenia ciała. Nadmienić przy tej okazji można, że także na morzach, u siedemnastowiecznych żeglarzy nierzadko przemocą mustrowanych na okręty, odnotowywano budzące zgrozę przypadki nostalgii. Ujawniały się one w postaci obłędu z napadami szału (calenture), co tłumaczono wzmożoną aktywnością tropikalnego słońca w strefach podzwrotnikowych, tak trudną do zniesienia dla Anglika i, oczywiście, oddaleniem od ojczystego kraju [Starobinski 2017: 190]. Tamtejszy, przednowoczesny strach przed nostalgią, był więc w swej istocie strachem przed śmiertelną chorobą i szybko opanował on Europę, podsycany licznymi wojnami prowadzonymi na kontynencie w wiekach: XVII-XIX.

\section{Ponowoczesna nostalgia}

Zasadniczy przełom w kształtowaniu się interesującego nas pojęcia przyniosła przenikliwa analiza problemu wyłożona przez Immanuela Kanta w rozprawie: Antropologia w ujęciu pragmatycznym, gdzie niemiecki filozof 
dowiódł, że właściwym obiektem tęsknoty nostalgika nie jest miejsce, jak utrzymywano przez długie dziesięciolecia, ale czas. Precyzując chodziło mu nie o czas wyabstrahowany z doświadczenia podmiotu, lecz o tempus odmierzany biografią i kolejnymi etapami życia. Zatem nostalgia uprzywilejowała sobie szczególnie czas, na który przypadało dzieciństwo i młodość, a do jakiego wrócić było nie sposób w dojrzałych latach życia. Dla Kanta wskrzeszenie przeszłego stanowiąc przykład estetyki wzniosłości było nawet zupełnie niemożliwe, ponieważ zakładał, że umysłowa reprezentacja doświadczenia jest z natury nieprzedstawialna. Argumentacja jest tutaj następująca: „to, co dając się pomyśleć, nie pozwala się uobecnić $\mathrm{w}$ przedstawieniu powstałym $\mathrm{w}$ wyobraźni i zarazem przypomnieniu" [Saryusz-Wolska, Traba 2014: 276]. Klęska reprezentacji spowodowana istnieniem rozziewu między pojęciem a niemożliwością przedstawienia wywołuje w podmiocie nostalgicznym specyficzny rodzaj afektu - wzniosłe wzruszenie, w jakim przyjemność zostaje przemieszana z bólem. Nader bolesny jest bowiem stan, „w którym człowiek czuje się oddzielony od ideału" [Starobinski 2017: 196], a tego rodzaju wewnętrzne rozdarcie przyczyniło się, zdaniem Starobinskiego, do kariery nostalgii w literaturze romantyzmu europejskiego. $W$ rezultacie ta nowoczesna myśl, będąc pochodną i konsekwencją wywiedzioną wprost z myśli Kanta, wykreowała nowego bohatera: młodzieńca nieprzystosowanego, wyobcowanego ze świata, nieszczęśliwego, kogoś $\mathrm{w}$ rodzaju faworyta epoki, czyli Wertera. Warto też dodać, że filozof z Królewca za siedlisko nostalgii uważał bardziej chorą wyobraźnię aniżeli obolałą pamięć [Zaleski 1996: 17]. Takie stanowisko Kanta nie powinno dziwić zważywszy na fakt, iż poprzedzało ono modernistyczną refleksję Marcela Prousta o możliwości i sposobie odnalezienia „utraconego czasu" w literaturze manifestującej wrażliwość nostalgiczną.

Przełomowa praca niemieckiego uczonego została ogłoszona na ponad wiek wcześniej nim współczesna psychologia poczyniła inne ważne odkrycie, nazwane „efektem reminiscencji”, którego analizie holenderski teoretyk pamięci poświęcił książki [Draaisma 2010; 2006]. Termin ten, odnosi się do funkcjonowania pamięci osób dojrzałych i oznacza niezależny od woli podmiotu nagły napływ wspomnień, przy czym często niezwykle zmysłowych i nacechowanych silnymi emocjami, a dotyczących wczesnych lat życia. We wspomnieniu z niezwykłą siłą ożywają wówczas nie tylko same obrazy, ale także smaki, zapachy i głosy. Istotne $z$ literaturoznawczego punktu widzenia będzie, że wspomnienia mają naturę narracyjną, zatem mentalne powroty do przeszłości wskazują na przebieg indywidualnej biografii zgodnie z logiką opowieści, dla której ma znaczenie, że oderwane, zdawałoby się, epizody dążą do jakiegoś finału, a po drodze zdarzają się niespodziewane zwroty akcji. Rzecz ta ma również drugą stronę, pozaliteracką, bo to, w jaki sposób ktoś konstruuje historię własnego życia kształtuje i jednocześnie odsłania jego 
tożsamość [Draaisma 2006: 243]. Źródeł fenomenu psychologowie doszukują się $\mathrm{w}$ dwu obszarach, albo $\mathrm{w}$ naturze pamięci, albo $\mathrm{w}$ rodzaju wspomnień. Nie ma też jednolitego wyjaśnienia roli pełnionej przez reminiscencje. Jedni uważają za kluczowy w sprawie rozwój mózgu i zdolności kognitywnych w młodości [Draaisma 2010: 87]. Drudzy są przekonani o wadze mechanizmów społecznych, przede wszystkim sprawnego obiegu tradycji między przedstawicielami różnych pokoleń oraz podtrzymywaniu tożsamości grupowej [Draaisma 2010: 89].

Poza tym nadmienić trzeba, że dwudziestowieczne reprezentacje nostalgii jako przykłady utopii warunkowane są przekonaniem o wyższości czasu minionego nad niepewną teraźniejszością, a poddane ciśnieniu sił historii odzwierciedlają świadomość aksjologicznego zagubienia w latach gwałtownych przemian, jak we współczesnej Rosji [Boym 2002]. Obserwacje Boym dotyczące pamięci postkomunistycznej wpisują się w szerszy kontekst, jakim jest doświadczenie ponowoczesnej deprywacji.

\section{Nostalgia polskich emigrantów}

Bliska doświadczeniu nostalgii przez niegdysiejszych żołnierzy jest tęsknota, często nieuleczalna, późniejszych emigrantów za opuszczoną ojczyzną. Pod hasłem: „emigracja” znajdziemy we współczesnym słowniku dwa podstawowe znaczenia. W pierwszym znaczeniu będzie to: "opuszczenie kraju ojczystego, stałe lub czasowe osiedlenie się poza granicami ojczyzny; wychodźstwo" [Słownik jezyka polskiego 2010], a przykładami zjawiska definiowanego w ten sposób są: „Emigracja stała, okresowa, polityczna, zarobkowa” [Słownik języka polskiego 2010]. Z kolei słowo „emigrant” jest synonimem politycznego banity: „ten, kto emigruje; wychodźca” [Stownik języka polskiego 2010].

W przypadku dziejów polskiego uchodźstwa wydarzeniem fundującym była przegrana powstania listopadowego w 1831 roku, która spowodowała powstanie nowego zjawiska społecznego, jakim jest emigracja polityczna, a nostalgia odczuwana przez jego uczestników dostarczyła kulturowego wzorca przeżywania doświadczenia emigracji przez Polaków w wieku dziewiętnastym i dwudziestym. Natomiast za sprawą narodowych wieszczów: Adama Mickiewicza, Juliusza Słowackiego, Zygmunta Krasińskiego i Cypriana Kamila Norwida, a także polityków: księcia Adama Czartoryskiego oraz genialnego kompozytora Fryderyka Chopina, na określenie tej formacji kulturowej przyjęła się nazwa „Wielka Emigracja”. Znawczyni tematu, Alina Witkowska, w monografii pod wiele mówiącym tytułem: Część $i$ skandale: o emigracyjnym doświadczeniu Polaków (1997) opisała emigrację polistopadową 
jako specyficzną formę kultury, wytworzoną przez samotnych i najczęściej bezżennych mężczyzn, zmuszonych przez zewnętrzne ośrodki represji do opuszczenia ojczystej ziemi, co najczęściej stawało się powodem dotkliwych udręk życiowych i licznych nieszczęść. Pod przygniatającym ciężarem egzystencji emigracyjnej wielu spośród nich „znajdowano z niej wyjście drastyczne i radykalne - samobójstwo" [Witkowska 1997: 43]. Dlatego wygnanie z przyczyn politycznych, podobnie do uwięzienia, należy rozpatrywać $\mathrm{w}$ kategoriach rany psychicznej, zogniskowanej na wielostronnym przeżyciu straty domu. W ten sposób refleksja o nostalgii zatacza hermeneutyczne koło, skupiając się ponownie na utracie rozpatrywanej $w$ kategoriach geograficznie rozumianej przestrzeni.

Przeszło sto pięćdziesiąt lat po wielkich romantykach Barbara Skarga, która w ZSRR została aresztowana i skazana za działalność w Armii Krajowej na wiele lat łagru na Syberii, problem uwięzienia i banicji poruszyła w eseju, wskazawszy na konsekwencje tożsamościowe ponoszone przez wygnańca. Zacytujmy fragment jej rozważań:

Wygnanie to nie tylko fakt społeczno-polityczny. To nie tylko wyzucie z mienia. To gwałt zadany memu byciu i możliwości odnalezienia siebie. To skazanie na zagubienie w tym, co obce, czego zrozumieć nie jestem w stanie. Mówimy wówczas o odcięciu od korzeni i w tym metaforycznym ujęciu jest gorzka prawda. Dom bowiem nie jest budynkiem, lecz miejscem, w które się wrasta, glebą, na której rodzi się moje Ja we wszystkich jego wymiarach [Skarga 1997: 271].

Wygnanie, czy nawet dobrowolne osiedlenie się poza granicami ojczystego kraju nierzadko (i nasza współczesność wcale nie jest od tego wolna), może wzbudzić uciążliwą nostalgię prowadzącą wprost do depresji, rozumianej dosłownie jako uciążliwa choroba.

Natomiast kompletnie odmienna była emigracja Stanisława Barańczaka, który w Ameryce znalazł się w sposób dobrowolny, choć okoliczności wyjazdu były spowodowane opozycyjną działalnością poety, który wpierw w 1977 roku został zwolniony dyscyplinarnie z polonistyki Uniwersytetu im. Adama Mickiewicza w Poznaniu, a później przywrócony do pracy, po interwencji „Solidarności”, we wrześniu 1980 roku. Do Stanów Zjednoczonych poeta wyjechał w marcu 1981 roku, z rodziną (z żoną Anną oraz dziećmi: Michałem i Anią) początkowo na roczny kontrakt $w$ prestiżowym Harvard University. W zbiorze esejów Tablica z Macondo (1990), wydanych w Londynie, Barańczak zawarł wrażenia i refleksje Polaka urodzonego w państwie pod rządami komunistów, który dodatkowo, po osiedleniu się w demokratycznym USA skonfrontował swoje doświadczenia wyniesione z kraju o socjalistycznym modelu gospodarki z realiami ustroju kapitalistycznego. Postać E. E. jako tekstowa reprezentacja emigranta ze Wschodu Europy (skrót: „E. E” odnosi się 
do angielskiego sformułowania „Eastern European”), w zamyśle autora eseju: E. E., przybysz z innego świata [Barańczak 1990], została upodobniona (fonetycznie, graficznie, mentalnie) do bohatera kultury masowej, niejakiego E. T., czyli fikcyjnego stworka z przebojowego filmu Stevena Spielberga (1982) pod identycznym tytułem. Wspólne im obu było, że każdy z nich okazał się w Ameryce, tak to ujmę: „przybyszem z innej planety”. Chronologicznie pierwszy, E. T., zjawił się w Nowym Świecie wprost z kosmosu, podczas gdy drugi, E. E., wysiadł z samolotu po transatlantyckim długim przelocie, dajmy na to, z Polski. Obaj natomiast byli wiecznie zdziwieni w zetknięciu z nową dla nich, amerykańską kulturą, co zbliża ich postaci do dziecięcego odbioru rzeczywistości albo do wrażliwości wybitnych poetów: Czesława Miłosza (Nobel 1980), Wisławy Szymborskiej (Nobel 1996) oraz Mirona Białoszewskiego, któremu Barańczak poświęcił książkę doktorską Język poetycki Mirona Białoszewskiego (1974). Rozpoczyna się ona częścią: W stronę języka dziecięcego.

Pierwsze kroki emigranta na obcym lądzie nasuwają mu porównanie z koniecznością korzystania z ruchomych schodów, co wymaga umiejętności utrzymania balansu z jednej strony, a z drugiej wskazuje na dokonujące się przyspieszenie tempa życia $\mathrm{w}$ amerykańskiej rzeczywistości. Stąd też mamy tu do czynienia z metaforą o charakterze egzystencjalnym, której celem jest oddanie wielowymiarowego wstrząsu przenosin. Już pierwszy haust powietrza, zaczerpnięty od razu po wyjściu z samolotu prowokuje szok narodzin dla nowego kraju. Powietrze jest czyste, w kontraście do zanieczyszczeń wywołujących konieczność stałego prowadzenia „walki o oddech”, czy natychmiastowego podjęcia reanimacji, owego "sztucznego oddychania", doświadczanego w PRL-u. Metafora oddechu charakteryzuje twórczość całej poetyckiej generacji Barańczaka. Występuje przecież w poezji Ewy Lipskiej, Ryszarda Krynickiego, Adama Zagajewskiego, Juliana Kornhausera [zob. Czabanowska-Wróbel, Misiak 2010]. Po szoku tlenowym przychodzą kolejne wstrząsy: "optyczny”, cywilizacyjny, kulturowy, a każdy z nich ujawnia nieporadność cechującą emigranta w początkach życia w nowym kraju, wyraża syndrom nieprzystosowania. Dla porównania polski eseista przywołuje postać nieco gapowatego Rosjanina, Pnina, uczącego w amerykańskim college'u (realia powieści Vladimira Nabokova Pnin), a samego rosyjskiego pisarza Barańczak proponuje uznać za stuprocentowego E. E. W eseju przytacza scenę, kiedy Pnin próbuje kupić w sklepie piłkę futbolową, a na propozycję sprzedawcy reaguje głośnym protestem: „Nie, nie - powiedział Pnin - nie chodzi mi o jajo ani o żadną torpedę. Szukam zwykłej piłki. Okrągłej! Po czym rozwarł dłonie w powietrzu, jak gdyby trzymał w nich przenośną kulę ziemską. Tym samym gestem posługiwał się przy kasie, kiedy mówił o harmonijnej całości Puszkina" [Barańczak 1990: 194]. Jednakże E. E. nie jest wyłącznie postacią humorystyczną, choć jego „przygody”, czyli najczęściej: gafy, pomyłki, 
lapsusy językowe, bywają niekiedy naprawdę zabawne, jak w zacytowanym fragmencie powieści Nabokova, nota bene wytrawnego klasyka nostalgii oraz jednego z ulubionych pisarzy Barańczaka.

Figura E. E. jest w istocie reprezentacją rozłamu biografii („tu i teraz”: „tam i kiedyś"), co nadaje egzystencji poza granicami ojczystego kraju rysów tragicznych, w każdym razie pesymistycznych. Wystarczy zajrzeć do emigranckiego Resume [Barańczak 2006: 298] poety z Poznania, żeby móc przekonać się o tym, że umiejętności przybysza ukształtowane $\mathrm{w}$ totalitarnym państwie, a czyniące zeń eksperta „na skalę wschodnioeuropejską w kwestiach odmowy zeznań i mówienia między wierszami" [Barańczak 2006: 298], co podkreśla z gorzką ironią, są w Ameryce kompletnie bezużyteczne. Za to brak mu kompetencji pożądanych w nowym miejscu, a więc przede wszystkim pewności siebie, owej „sztuki nieskrępowanego uśmiechu” [Barańczak 2006: 298] i śmiałości w podejmowaniu planów życiowych. Jakkolwiek Barańczak zawsze gwałtownie odżegnywał się od etykiety politycznego emigranta, czego wymownym przykładem jest inny utwór: Nie używać słowa "wygnanie" [Barańczak 2006: 303], to na skutek obrotu historii w końcu i on nim został, kiedy 13 grudnia 1981 roku wprowadzono w Polsce stan wojenny, odcinając szanse na powrót do ojczyzny na zawsze. Czy ktoś mógł wówczas przypuszczać, że upadek rządu komunistów w Polsce, to kwestia nieodległej przyszłości, dokładnie ośmiu lat?

\section{Nostalgiczny sen Stanisława B.}

Poetyckich poprzedników i mistrzów w „sztuce nostalgii” w wieku dwudziestym miał Stanisław Barańczak znakomitych: Kazimierz Wierzyński [Rydz 2004] i Czesław Miłosz [Rydz 2011], których historia totalitarna rzuciła na obcy kontynent, do Ameryki Północnej. Utrwalili oni w swojej twórczości indywidualne wzorce "ćwiczeń" z utraty i odnajdywania, a poznański poeta podążając niejako po ich śladach wytyczył własną emigracyjną ścieżkę. Każdy z wymienionych na swój sposób poczynił prywatne odkrycie w swej egzystencji, że wraz $\mathrm{z}$ upływem lat na obcej ziemi przybysz ulega $\mathrm{w}$ końcu procesowi domestykacji, co jednak w niczym nie kończy jego emigracyjnych perypetii, a jedynie domyka ich wstępny rozdział. Więcej nawet - dobrze służy rozkwitowi wrażliwości nostalgicznej, choć pozornie jest to sytuacja nielogiczna, kłócąca się z wreszcie osiągniętym i upragnionym zadomowieniem. Ale, gdy ustąpią trudności adaptacyjne w pierwszych latach poza ojczyzną, a życie w nowym kraju stanie się już szczęśliwie „drugą naturą" człowieka, jak w wierszu Barańczaka pod takim tytułem [Barańczak 2006: 302], gdy przywyknie: oko (do orgii kolorów i rozmiaru rzeczy), ręka (do odmiennej pisowni cyfry „siedem”), język (do 
poprawnej artykulacji dźwięku "the"), to wówczas nostalgia wyjdzie z ukrycia i zaatakuje. Podstępnie, we śnie. Bowiem pod natłokiem zdarzeń codzienności nostalgia istnieje niejako zahibernowana w zwodniczym "uśpieniu", lecz naprawdę cały czas pozostaje gotowa, by niby drapieżnik pojawić się znienacka i pochwycić bezbronną ofiarę w swoje szpony:

Po paru latach śni się sen:

stoisz przy zlewie w kuchni leśniczówki

w pobliżu miejscowości Sieraków, gdzie po maturze, nieszczęśliwie zakochany spędzałeś wakacje

twoja lewa dłoń unosi czajnik, prawa kieruje się w stronę gałki kranu.

Sen, jakby uderzył w ścianę, staje nagle w miejscu,

z męczącym natężeniem skupiając się na niepewnym szczególe:

czy gałka była porcelanowa czy mosiężna.

Śpiąc jeszcze, wiesz przeraźliwie jasno, że od tego wszystko zależy.

Budząc się, wiesz równie jasno, że nigdy się nie przekonasz.

[Barańczak 2006: 302]

W końcowej glosie do losów politycznych wygnańców doby romantycznej wytrawna badaczka polskiej literatury tamtego czasu stwierdziła: „Oni inaczej cierpią, inne choroby im dolegają - nostalgia, depresja - częstokroć odmienną drogą zmierzają ku śmierci: poprzez samobójstwo" [Witkowska 1997: 193]. Dodam do komentarza Witkowskiej, że emigranci również - inaczej śnią. A badania współczesnych badaczy pamięci dowodzą tego faktu ponad wszelką wątpliwość. Okazuje się regułą, że sny młodych emigrantów dotyczą zwykle minionego dzieciństwa i lat wczesnej młodości, a starszych trudu początków w miejscu osiedlenia, i - paradoksalnie - mimo nierzadko dziesiątków lat spędzonych szczęśliwie w drugim kraju, w nostalgicznych snach powracają oni do posługiwania się językiem ojczystym, jakby ich dawne doświadczenie stale przezierało we śnie i przedzierało się przez bieżące, codzienne, sprawy [Draaisma 2010: 168]. „W taki sposób człowiek śni o dwóch życiach" [Draaisma 2010: 168]. W utworze Barańczaka Druga natura przedstawioną prawidłowość ilustruje przywołany fragment wiersza, rozpoczęty przecież reminiscencją wakacyjnej sceny mającej miejsce latem, krótko po maturze, a przywołanej we śnie i budzącej śpiącego. Zwróćmy uwagę, że dla niejako „reaktywowanej” na sposób oniryczny świadomości emigranta charakterystyczne jest występowanie pewnego schematu, pewnej sekwencji zdarzeń, bardzo dobrze odnotowane w polskiej poezji (Miłosza, Wierzyńskiego, Iwaniuka). Otóż, nostalgik zostaje nagle i gwałtownie wybudzony ze snu, jakby dosłownie został: "przebity światłem jak sztyletem", bo taką sugestywną metaforą synestezyjną specyficzną "przemoc" snu wobec śniącego wyraził Kazimierz Wierzyński, autor onirycznego tomu wierszy Sen mara (1969). 
Warto także podkreślić, że $\mathrm{w}$ dyskursie nostalgii ma swój przemożny udział „dramat” i jednocześnie - dramaturgia wygnania, czy szerzej, emigracji. W poezji znajduje ona częstą reprezentację w uobecnieniu koszmaru sennego, powracającego z cykliczną regularnością, a to z kolei wskazuje już na prywatną obsesję śniącego podmiotu. W wierszu Barańczaka nie sen „uderza” przecież w mur, tylko jaźń śniącego emigranta kapituluje przed barierą nie do przezwyciężenia na danym etapie jego egzystencji. Przedstawienie nostalgii nie bez przyczyny niejednokrotnie uzyskuje kształt oniryczny, ponieważ uporczywość snu, w którym film dawnego życia zatrzymuje się w jednym i tym samym momencie, do tego doskonale znanym śniącemu z wcześniejszych snów, wywołuje prawdziwą udrękę podmiotu, której (na co wskazują badania psychologiczne prowadzone w naszym stuleciu), nie daje się niczym uśmierzyć. Dodatkowo, wizyty nostalgika w wytęsknionym domu, zaostrzają tylko jego depresyjny stan po powrocie [Draaisma 2010: 178]. Nie taka była jednak sytuacja Barańczaka do 1989 roku. Wiadomo, że nostalgia Adama Mickiewicza za rodzinną Litwą zmaterializowała się w złowieszczą ciszę na bezkresnym jak Rosja i bezkresnym jak samo wygnanie - stepie Akermanu: „W takiej ciszy! - tak ucho natężam ciekawie, / Że słyszałbym głos z Litwy. - Jedźmy, nikt nie woła" [Mickiewicz 1986: 81]. U Barańczaka, co jest chyba jeszcze gorsze, niż w romantycznym wzorcu, nostalgia przybiera w wierszu formę upiornego refrenu. Manifestuje swą obecność w przypomnieniu stanu jakiegoś egzystencjalnego zawieszenia, za to trwającego „bez końca”, przez co napełnia on życie politycznego exula nieznośnym bólem. Szczególna wiedza płynąca "jasno" z przekazu we śnie zapowiada nader stanowczo, „że nigdy się nie przekonasz". O czym? O błahostce: „czy gałka była porcelanowa czy mosiężna” [Barańczak 2006: 302], która zatruwa obolałą pamięć wygnańca. Upragniona odpowiedź zostaje bowiem przewrotnie wpisana w kondycję emigranta politycznego, przed którym szczelnie zamknięte są bramy ojczyzny. Nigdy już nie zobaczy on rodzinnych stron, ponieważ nie ma wyboru, który jest przywilejem wolnego człowieka.

\section{Nostalgiczny wrzesień Stanisława B.}

Dyskurs nostalgii, prócz dojmującej tęsknoty emigranta za domem, przybiera również formę łagodniejszą, oczyszczoną z bólu, płynącą z akceptacji siebie w nowym miejscu. Na początku jesieni, nic nie zapowiada wznowienia nieuleczalnej tęsknoty, konotowanej w kulturze przez tę porę roku, łączoną z melancholią, lecz po prostu oznacza podjęcie obowiązków zawodowych po letniej przerwie. W ten sposób Barańczak zarysowuje realistyczną płaszczyznę świata przedstawionego w utworze Wrzesień, a tytułowy miesiąc zapo- 
wiada już, w dobrym sensie tego słowa: uniwersytecką rutynę, odmierzaną kalendarzem zajęć i egzaminów, uczelnianymi rytuałami, przede wszystkim zaś spodziewanym biegiem powszednich spraw. Stąd też, w typowym uczelnianym miejscu, „w pokoju z biurkiem, tablicą i nie dającym się otworzyć oknem / (klimatyzacja)" [Barańczak 2006: 299], widzimy profesora Barańczaka w trakcie zajęć ze studentami: w "grupie złożonej z Mulata, Japonki, dwojga Anglosasów, / nowojorskiego Żyda i kalifornijskiej Irlandki" [Barańczak 2006: 299]. Zaskakiwać może fakt, że pięcioro seminarzystów, na retorycznej zasadzie pars pro toto, stanowi w tym wierszu reprezentację całej Ameryki, w jej etnicznym, kulturowym i językowym zróżnicowaniu. Porównajmy spostrzeżenie poety utrwalone w eseju (E. E., przybysz z innego świata) o wielobarwności egzystencji doświadczanej w USA:

Beztroski rozmach, z jakim pomalowano Amerykę, wydaje mu się wstrząsająco - ale sympatycznie - odmienny od jednostajnej bezbarwności, która w jego ojczyźnie wydaje się spowijać i nasączać wszystko: ulice, osiedlowe bloki, samochody, twarze... Kolorem Europy Wschodniej jest, jak wiadomo szarość (ożywiana tylko przebłyskami czerwieni z okazji świąt państwowych). Ameryka nie ma określonego koloru: jest jaskrawo wielobarwna, kolorystycznie pluralistyczna, już na pierwszy rzut oka wieloznaczna i śmiała [Barańczak 1990: 191].

Nieważne, czy z daleka (Europa, Azja, Afryka), czy z bliska (Kalifornia i Nowa Anglia), ale każdy z uczestników uniwersyteckiej scenki rodzajowej w utworze Barańczaka skądś przybył do Uniwersytetu Harvarda. Nikt nie jest "stąd". Konstatacja powyższa wprowadza trudną do uchwycenia w pierwszej chwili aurę, bliżej niesprecyzowanej, delikatnej nostalgii. Samotność profesora, gdy objaśnia studentom wers Ody do młodości narodowego wieszcza, Mickiewicza: "goniąc za żywiołkami drobniejszego płazu” [Barańczak 2006: 299] nie jest wyłącznie znakiem alienacji emigranta, chociaż od japońskiej studentki oddziela go „Bałtyk spółgłosek” wskazujący raz: na odmienność kulturową studentów i wykładowcy pochodzących z krajów o odmiennej tradycji, dwa: na "szumiącą" jak szmer wody polszczyznę, obcą uczestnikom zajęć profesora, trzy: na wodę, na Atlantyk, który oddziela Barańczaka od „rodzinnej Europy”, by przywołać formułę Miłosza. Wprowadzenie motywu Morza Bałtyckiego do wiersza jest na pewno odwołaniem do Polski w jej geograficznym usytuowaniu na politycznej mapie świata, ale jednocześnie oznacza kraj: wyobrażony, intymny, noszony pod powiekami. Aczkolwiek aluzje przestrzenne są istotne, to stawką, o jaką toczy się tutaj poetycka rozgrywka z samym sobą, okaże się jednak czas, nie miejsce. Bardziej chyba niż z sytuacją emigracyjnego nieprzystosowania stykamy się w utworze nieoczekiwanie, na moment, z wyobcowaniem egzystencjalnym. Bohater Barańczaka wchodzi oto w Conradowską "smugę cienia": 
Skończyło się, dawno temu. Co? Młodość. W promieniu

Co najmniej mili $(1609,31 \mathrm{~m})$

jeszcze przez dobre pięć minut oprócz niego nie będzie nikogo,

kto by wiedział, co znaczą słowa "spólny łańcuch” oraz „ziemskie kolisko”.

[Barańczak 2006: 299]

Ekspozycji temporalnej podporządkowana zostaje cała kompozycja tego znakomitego w swej lapidarności wiersza poety, dla którego Poznań jest miejscem autobiograficznym. Czas sygnalizowany w formule tytułowej: Wrzesień (co nasuwa naturalnie skojarzenia z powrotem do szkolnych lawek), uobecnia się zwielokrotniony w intertekstualnym przywołaniu Mickiewiczowskiej ody. Romantyczny utwór będący już manifestem nowej, obudzonej w dziewiętnastym wieku rewolucyjnej wrażliwości, ze świadomego przeżywania młodości wyprowadza przecież postulat i zarazem powinność reformowania świata, ulepszania go i modernizowania. A wyznanie z końca wiersza odbieram głównie jako autobiograficzne świadectwo przeżycia czasu przez autora Tryptyku z betonu, zmęczenia i śniegu (1980), utworu symptomatycznego dla realiów życia w Polsce końca lat 70. XX wieku, również w Poznaniu. Z kolei utrzymany w subtelnej tonacji emocjonalnej tęsknoty Wrzesień Barańczaka uwypukla tyleż refleksyjny, co konsolacyjny aspekt omawianego fenomenu nostalgii. Młodość, o którą się tu rozchodzi, rozumiana dosłownie - jako wczesny etap życia, czy pora uniwersyteckiej edukacji - uobecnia się w wierszu wpierw w osobach "amerykańskich” studentów, wykładowcy z Polski, by chwilę później, w domyśle, na „dobre pięć minut” przed końcem zajęć przywołać niegdysiejszą, wileńską młodość Mickiewicza oraz utraconą poznańską młodość Barańczaka. Niewidzialny łącznik z Mickiewiczowskiej ody spiął symbolicznie dwudziestowieczną biografię z historią dziewiętnastowiecznych rodaków w jedno. Zatem metaforycznie utworzony "łańcuch” opasuje nie „ziemskie kolisko” w sensie geograficznym, lecz w błysku epifanii wprowadza jedność wszystkich czasów przywołanych z przeszłości i z różnych przestrzeni z teraźniejszością. Paradoksalnie, unieważnia on czas, choć zasadniczo chodzi tu o tempus. W zakończeniu wiersza Barańczaka wybija się sens ponadjednostkowego pojmowania nostalgii, rozumianej jako przenoszenie rodzimej tradycji w sztafecie pokoleń, a praktyka tego rodzaju może poskutkować niczym lek, poszukiwany przez osiemnastowiecznych medyków na trapiącą ówczesnych pacjentów, nieuleczalną tęsknotę.

Parę wniosków na zakończenie. Można - jak sądzę - przednowoczesną nostalgię porównać do późniejszego strachu przed gruźlicą w XIX wieku, do AIDS w latach 80. dwudziestego wieku i do dzisiejszego strachu przez rakiem. O tym zresztą, że występuje ścisła zależność między straszną chorobą, śmiertelną, na którą nie wynaleziono jeszcze leku, a legendą utworzoną na jej temat, kiedy szybko i bez przeszkód rozprzestrzeniania się ona w społeczeń- 
stwie, pisała sugestywnie i przekonująco Susan Sontag w monograficznym opracowaniu problemu [Sontag 1999].

Zauważmy, że reprezentacje nostalgii występujące $\mathrm{w}$ polskiej poezji, również $\mathrm{w}$ wierszach Barańczaka, odsłaniają $\mathrm{w}$ dyskursie chiazmatyczną zależność: to, co indywidualne (osobiste wspomnienie) wpisuje się $\mathrm{w}$ doświadczenie zbiorowości (kultura pamięci). A z drugiej strony: to, co zbiorowe (wspólnota losu) warunkuje, określa, dopełnia, wszystko to, co zostało doznane w indywidualnej biografii. Przy czym, prawidłowość ta stosuje się w obu formach nostalgicznych reprezentacji: po- i nowoczesnych.

Ponowoczesna nostalgia, ufundowana na wieloaspektowym przeżyciu wykorzenienia, ma w polskiej tradycji literackiej źródło w historii Wielkiej Emigracji, od której oddala się ona i przybliża w dwudziestowieczności, co można zaobserwować na przykład w onirycznym uobecnieniu emocji wygnania w wierszu Barańczaka Druga natura. Właśnie nostalgiczna wrażliwość czyni egzystencję emigranta rzeczywistością „poniekąd laboratoryjną: prawdziwą i sztuczną jednocześnie” [Witkowska 1997: 195]. „Prawdziwą", bo każdorazowo popartą autorytetem autobiografii, lecz "sztuczną", gdyż odcięta od ojczystej topografii świadomość emigranta poszukuje pocieszenia? konsolidacji? "gdzieś" w świecie poezji, czego dowodzi analizowany Wrzesień. Nostalgia może wszakoż przybierać formę kiczu, narodowego mitu z tendencją do metamorfozy w nacjonalizm, skłaniać również do tęsknoty za komunizmem jako najlepszą z epok, czego dowodzą prace Svetlany Boym [Boym 2002] i Przemysława Czaplińskiego [Czapliński 2001].

\section{Bibliografia}

Barańczak S. 1990. Tablica z Macondo. Osiemnaście prób wyttumaczenia, po co i dlaczego się pisze, Londyn: Aneks.

Barańczak S. 2006. Wiersze zebrane, Kraków: a5.

Barańczak S. 2016. Język poetycki Mirona Białoszewskiego, Wrocław: Ossolineum.

Boym S. 2002. Nostalgia i postkomunistyczna pamięć, [w:] F. Modrzejewski, M. Sznajderman (red.), Nostalgia. Eseje o tęsknocie za komunizmem, tłum. zb., Wołowiec: Wydawnictwo Czarne.

Czabanowska-Wróbel A., Misiak I. (red.) 2010. Żywioły wyobraźni poetyckiej pokolenia '68, Kraków: Wydawnictwo Uniwersytetu Jagiellońskiego.

Czapliński P. 2001. Wznioste tęsknoty. Nostalgie w prozie lat dziewięćdziesiątych, Kraków: Wydawnictwo Literackie.

Draaisma D. 2006. Dlaczego czas płynie szybciej, gdy się starzejemy, przeł. E. Jusewicz-Kalter, Warszawa: Państwowy Instytut Wydawniczy.

Draaisma D. 2010. Fabryka nostalgii. O fenomenie pamięci wieku dojrzałego, przeł. E. Jusewicz-Kalter, Wołowiec: Wydawnictwo Czarne. 
Mickiewicz A. 1986. Wybór poezyj, t. 2, oprac. C. Zgorzelski, Wrocław: Wydawnictwo Ossolineum.

Nostalgia, [w:] M. Saryusz-Wolska, R. Traba (red.) 2014. Modi memorandi. Leksykon kultury pamięci, Warszawa: Wydawnictwo Naukowe Scholar.

Rydz A. 2004. Sztuka nostalgii. "Świat nie ma sensu. Sens ma sztuka”. O powojennej poezji Kazimierza Wierzyńskiego, Warszawa: Wydawnictwo Naukowe Semper.

Rydz A. 2011. Mnemozyna. O pamięci autobiograficznej w poezji polskiej, Poznań: Wydawnictwo Naukowe UAM.

Skarga B. 1997. Tożsamość i różnica. Eseje metafizyczne, Kraków: Znak.

Stownik języka polskiego PWN. 2004. Warszawa: Wydawnictwo PWN.

Sontag S. 1999. Choroba jako metafora. AIDS i jego metafory, przeł. J. Anders, Warszawa: Państwowy Instytut Wydawniczy.

Starobinski J. 2017. Atrament melancholii, przeł. K. Belaid, Gdańsk: Słowo/obraz terytoria.

Witkowska A. 1997. Część i skandale: o emigracyjnym doświadczeniu Polaków, Gdańsk: Słowo/ obraz terytoria.

Zaleski M. 1996. Formy pamięci, Warszawa: Wydawnictwo IBL. 
